\title{
Impaired humoral immunity in X-linked lymphoproliferative disease is associated with defective IL-10 production by CD4+ T cells
}

\author{
Cindy S. Ma, ${ }^{1,2}$ Nathan J. Hare, ${ }^{1}$ Kim E. Nichols, ${ }^{3}$ Loic Dupré, ${ }^{4}$ Grazia Andolfi, ${ }^{4}$ \\ Maria-Grazia Roncarolo, ${ }^{4,5}$ Stephen Adelstein, ${ }^{6}$ Philip D. Hodgkin,7 and Stuart G. Tangye ${ }^{1}$ \\ ${ }^{1}$ Centenary Institute of Cancer Medicine and Cell Biology, Newtown, New South Wales, Australia. ${ }^{2}$ Department of Experimental Medicine, University of Sydney, \\ Sydney, New South Wales, Australia. 3Division of Paediatric Oncology, Children's Hospital of Philadelphia, Philadelphia, Pennsylvania, USA.

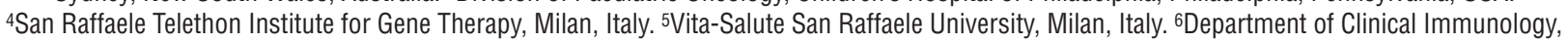 \\ Royal Prince Alfred Hospital, Camperdown, New South Wales, Australia. ${ }^{7}$ Walter \& Eliza Hall Institute of Medical Research, Parkville, Victoria, Australia.
}

\begin{abstract}
$\mathrm{X}$-linked lymphoproliferative disease (XLP) is an often-fatal immunodeficiency characterized by hypogammaglobulinemia, fulminant infectious mononucleosis, and/or lymphoma. The genetic lesion in XLP, SH2D1A, encodes the adaptor protein SAP (signaling lymphocytic activation molecule-associated [SLAM-associated] protein); however, the mechanism(s) by which mutations in SH2D1A causes hypogammaglobulinemia is unknown. Our analysis of 14 XLP patients revealed normal B cell development but a marked reduction in the number of memory $B$ cells. The few memory cells detected were $\operatorname{IgM}^{+}$, revealing deficient isotype switching in vivo. However, XLP B cells underwent proliferation and differentiation in vitro as efficiently as control B cells, which indicates that the block in differentiation in vivo is $B$ cell extrinsic. This possibility is supported by the finding that XLP $\mathrm{CD}^{+} \mathrm{T}$ cells did not efficiently differentiate into $\mathrm{IL}_{-10^{+}}$effector cells or provide optimal $\mathrm{B}$ cell help in vitro. Importantly, the B cell help provided by SAP-deficient $\mathrm{CD}^{+} \mathrm{T}$ cells was improved by provision of exogenous IL-10 or ectopic expression of SAP, which resulted in increased IL-10 production by T cells. XLP CD4 ${ }^{+} \mathrm{T}$ cells also failed to efficiently upregulate expression of inducible costimulator (ICOS), a potent inducer of IL-10 production by $\mathrm{CD}^{+} \mathrm{T}$ cells. Thus, insufficient IL-10 production may contribute to hypogammaglobulinemia in XLP. This finding suggests new strategies for treating this immunodeficiency.
\end{abstract}

\section{Introduction}

$\mathrm{X}$-linked lymphoproliferative disease (XLP) is an often-fatal immunodeficiency, characterized by fulminant infectious mononucleosis, hypogammaglobulinemia, and malignant lymphoma (1-3). The gene mutated in XLP is SH2D1A, which encodes the adapter protein signaling lymphocytic activation molecule-associated protein (SAP) (4-6). SAP binds to the cytoplasmic domains of various cell surface receptors (signaling lymphocytic activation molecule [SLAM], 2B4, CD84, Ly9, NTB-A) expressed on hematopoietic cells that deliver activation signals following interactions with their cognate ligands (4, 7-14). Mutations in SH2D1A are believed to compromise the signaling pathways elicited by these SAP-associating receptors (3).

SAP-deficient mice (denoted as $\mathrm{SAP}^{-/-}$mice) display impaired humoral immune responses to $\mathrm{T}$ cell-dependent Ag, as evidenced by the absence of germinal centers (GCs) and deficiencies in Ag-specific memory B cells, plasma cells, and serum antibodies (15-19). This defect was previously shown to be corrected by adoptively transferring SAP-sufficient $\mathrm{CD} 4^{+} \mathrm{T}$ cells (18), which suggests an extrinsic B cell abnormality. However, the mechanism whereby SAP

\footnotetext{
Nonstandard abbreviations used: APC, allophycocyanin; BMT, bone marrow transplantation; CVID, common variable immunodeficiency; GC, germinal center; ICOS, inducible costimulator; ICOS-L, ICOS ligand; PB, peripheral blood; PerCp, peridinin chlorophyll; PHA, phytohemagglutinin; rIL-2, recombinant human IL-2; SAP, signaling lymphocytic activation molecule-associated protein; SA-TC, streptavidin-tricolor; SLAM, signaling lymphocytic activation molecule; TCL, T cell line; $\mathrm{T}_{\mathrm{FH}}$ cells, follicular T helper cells; XLP, X-linked lymphoproliferative disease.

Conflict of interest: The authors have declared that no conflict of interest exists.

Citation for this article: J. Clin. Invest. 115:1049-1059 (2005).

doi:10.1172/JCI200523139.
}

regulated the helper function of $\mathrm{CD} 4^{+} \mathrm{T}$ cells in this model was not determined. Although $\mathrm{SAP}^{-/-}$mice phenocopy many aspects of XLP, there are some limitations to this model of the human disorder. For instance, mice are not susceptible to infection with EBV (20), the main trigger for the onset of $\mathrm{XLP}(1,2)$, and $\mathrm{SAP}^{-/-}$mice have not been reported to develop lymphoma, a common clinical manifestation of XLP $(1,2)$. Therefore, in order to gain an understanding of the role of SAP in the human immune system, it is important to examine cellular and molecular responses directly in XLP patients.

Here we investigated the effect of SH2D1A mutations on the development and function of B cells in XLP patients compared to healthy controls and patients with common variable immunodeficiency (CVID) who also have unexplained hypogammaglobulinemia $(21,22)$. Our studies revealed that all patients with XLP, but not those with CVID, exhibited a severe deficiency in circulating memory B cells. The few memory B cells that developed in XLP patients were predominantly $\mathrm{IgM}^{+}$, demonstrating reduced Ig isotype switching in vivo. XLP B cells responded to T cell-dependent stimuli in vitro as efficiently as normal B cells. In contrast, activated $\mathrm{CD} 4^{+} \mathrm{T}$ cells from some XLP patients failed to provide B cell help for Ig production by cocultured allogeneic normal B cells, demonstrating that the defect in Ig production is B cell extrinsic and due to defective $T$ cell help. We identified, as a possible cause for this defect, reduced production of IL- 10 by $\mathrm{CD} 4^{+} \mathrm{T}$ cells from all XLP patients examined. In addition, XLP CD4 ${ }^{+} \mathrm{T}$ cells failed to efficiently upregulate the expression of inducible costimulator (ICOS), a potent inducer of IL-10 production (23). These combined abnormalities may contribute to the humoral immune defect in XLP and may be unique to the human disease because, unlike in human B cells (24), IL-10 
Table 1

Features of XLP patients

\begin{tabular}{|c|c|c|c|c|c|}
\hline Patient & Clinical phenotype & EBV infection & Intravenous Ig & Mutation & Effect on SAP \\
\hline No. 1 & $\begin{array}{l}\text { FIM, hypog, lymphoma, } \\
\text { hemophagocytosis }\end{array}$ & Yes & Yes & Missense & Y54C, reduced SAP \\
\hline No. 2 & FIM, hypog & Yes & Yes & Missense & F87S, reduced SAP \\
\hline No. 3 & FIM, hypog & Yes & Yes & Missense & F87S, reduced SAP \\
\hline No. 4 & Aplastic anemia & No & No & Missense & I84T, reduced SAP \\
\hline No. 5 & Control & No & No & Missense & I84T, reduced SAP \\
\hline No. 7 & Control & No & No & Missense & I84T, reduced SAP \\
\hline No. 8 & FIM, hypog & Yes & Yes & Missense & I84T, reduced SAP \\
\hline No. 9 & FIM, hypog, lymphoma & Yes & Yes & Frameshift & V102X, truncated SAP \\
\hline No. 10 & Eosinophilia & No & No & Missense & R55X, truncated SAP \\
\hline No. 11 & Hypog & Yes & Yes & Deletion & No SAP \\
\hline No. 14 & Unknown & Unknown & Unknown & Deletion & No SAP \\
\hline No. 15 & Hypog & No & Yes & Unknown & Reduced SAP \\
\hline No. 16 & Hypog, lymphoma & Unknown & Yes & Missense & I84T, reduced SAP \\
\hline No. 17 & Hemophagocytosis & Yes & Yes & Missense & Y76X, truncated SAP \\
\hline
\end{tabular}

FIM, fulminant infectious mononucleosis; hypog, hypogammaglobulinemia. data not shown) $(14,26)$, and several of these patients have been described previously $(14,27)$. A mutation in SH2D1A in XLP no. 15 could not be detected, which was also the case with some other XLP patients (28); however, this patient's MNCs lacked expression of SAP (data not shown).

$X L P$ patients have a severe reduction in the frequency of memory $\left(\mathrm{CD} 27^{+}\right)$ $B$ cells. The B cell compartment of XLP patients was compared to that of controls and CVID patients, who are also hypogammaglobulinemic but SAP sufficient (our unpublished data). In XLP patients, the average frequency of $B$ cells $\left(\mathrm{CD} 20^{+}\right)$within the peripheral blood (PB) lymphocyte population was $14.2 \% \pm 2.5 \%$ (mean \pm SEM; $n=14$; Figure 1A). A similar fre-

does not support the proliferation and differentiation of murine $B$ cells (25). These findings may allow the development of new therapies for the treatment of XLP as well as other immunodeficiencies that present with hypogammaglobulinemia.

\section{Results}

XLP patients. In this study, 14 XLP patients, aged 10-49 years, from 9 different families were investigated. The clinical features of these patients, as well as SH2D1A mutations and EBV status, are listed in Table 1 . All of these mutations drastically reduced or eliminated SAP expression by activated mononuclear cells (MNCs; quency was observed for healthy individuals $(9.6 \% \pm 0.6 \% ; n=21)$ and CVID patients $(8.3 \% \pm 1.5 \% ; n=18$; Figure $1 \mathrm{~A})$. When the number of B cells per milliliter of blood was enumerated, there was no statistical difference between XLP patients and healthy individuals or CVID patients (Figure $1 \mathrm{~A}$ ).

Analysis of the PB B cell compartment of healthy controls and CVID patients revealed that $29.2 \% \pm 2.8 \%$ (range $4.5-51.5 \% ; n=21$ ) and $20.5 \% \pm 4.2 \%$ (range $0.3-64.8 \% ; n=17$ ), respectively, were memory cells, identified by expression of CD27 $(13,29,30)$ (Figure 1B). The results for controls were consistent with previous findings that examined $\mathrm{CD} 27^{+}$cells within the B cell compartments of healthy
A

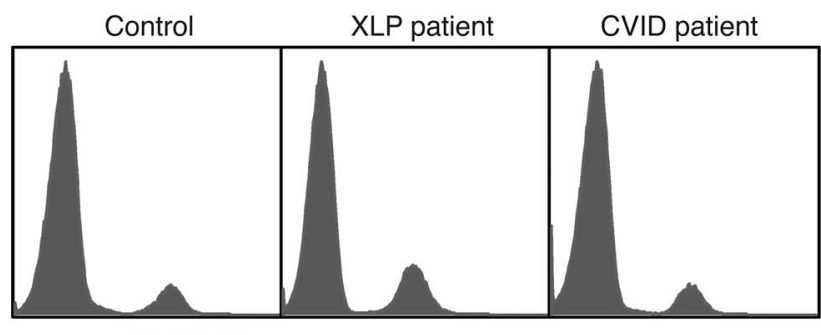

CD20

\section{$\mathbf{B}$}
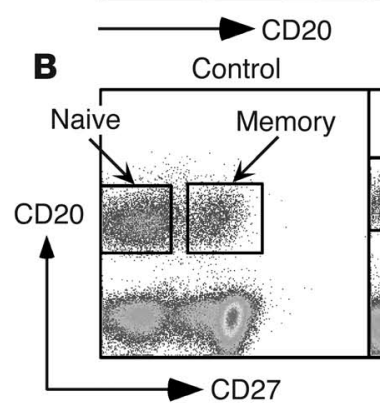

\begin{abstract}
XLP patient
\end{abstract} CVID patient

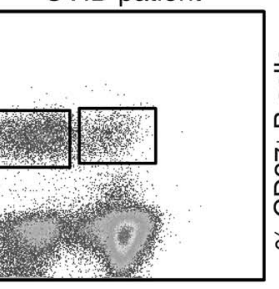

CD27
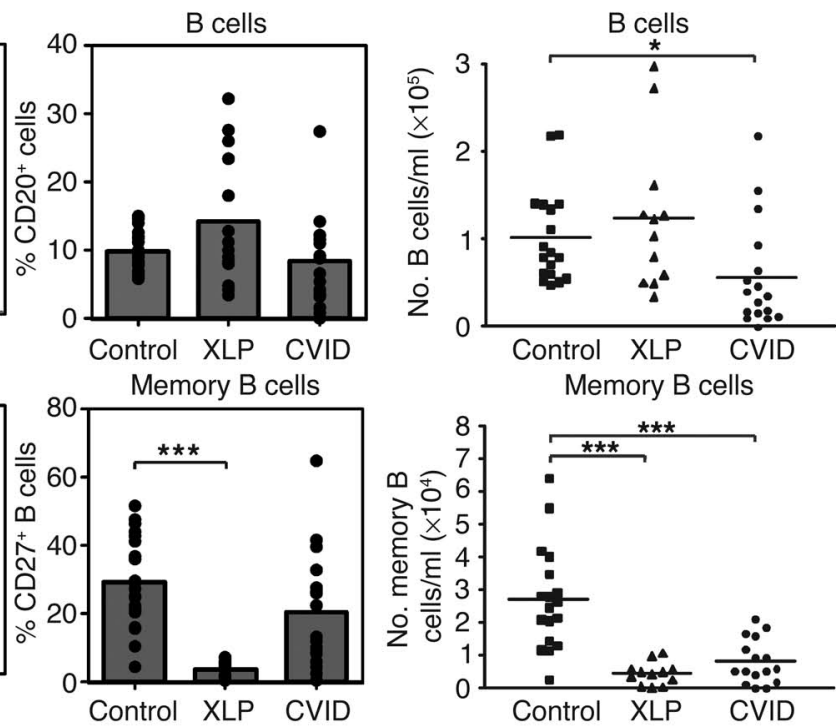

Figure 1

XLP patients have a severe reduction of memory (CD27+) B cells. (A) PBMCs from 21 healthy donors, 14 XLP patients, and 18 CVID patients were labeled with anti-CD20 mAb, and the frequency of B cells in the lymphocyte population was determined. The number of $B$ cells per milliliter of blood was then enumerated. (B) PBMCs were labeled with anti-CD20 and anti-CD27 mAbs and the frequency and number of memory $\left(\mathrm{CD} 27^{+}\right) \mathrm{B}$ cells $/ \mathrm{ml}$ of blood were quantitated. The histogram $(\mathbf{A})$ and dot plots $(\mathbf{B})$ are from 1 representative healthy donor, 1 XLP patient, and 1 CVID patient. The graphs show the data points for all donors and patients examined, with the mean frequency and number of cells per milliliter represented by the column graphs and horizontal lines, respectively. Significant differences are indicated. ${ }^{*} P<0.05 ;{ }^{* \star *} P<0.001$. 
A

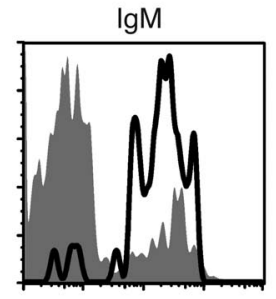

B $\lg \mathrm{M}$
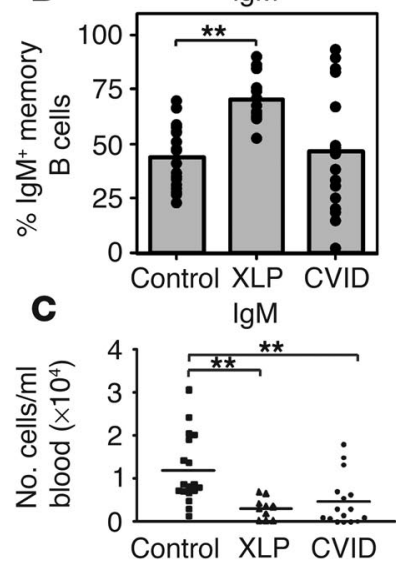
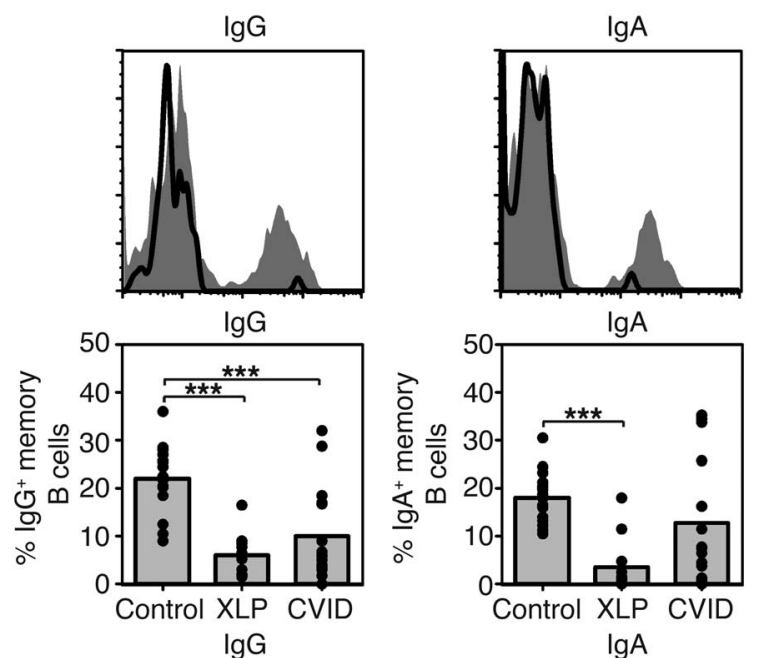

$\lg \mathrm{A}$
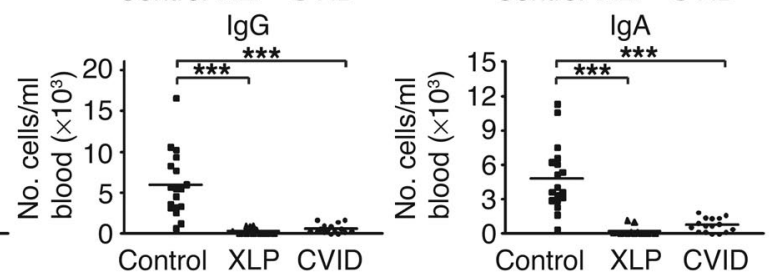

Figure 2

$\mathrm{B}$ cells fail to undergo isotype switching in vivo in XLP patients. PBMCs from 18 healthy donors, 12 XLP patients, and 18 CVID patients were labeled with mAbs specific for CD20, CD27, and either $\operatorname{lgM}, \lg G$, IgA, or an isotype control Ab. (A) Expression of surface lg isotypes by memory $\mathrm{B}$ cells in healthy donors (solid histogram) and XLP patients (overlay histogram) was determined by gating on $\mathrm{CD} 2 \mathrm{O}^{+} \mathrm{CD} 27^{+}$cells. The percentage $(\mathbf{B})$ and number $(\mathbf{C})$ of memory B cells that expressed lgM, IgG, or IgA was then calculated. The graphs show the data points for all donors and patients examined, with the mean frequency and number of cells per milliliter of blood represented by the column graphs and horizontal lines, respectively. Significant differences are indicated. ${ }^{\star \star} P<0.01$; ${ }^{\star \star \star} P<0.001$.

subjects older than 1 year (i.e., 10-40\%; ref. 31). By contrast, a marked decrease in the frequency of memory B cells was observed in all XLP patients examined $(3.4 \% \pm 0.5 \%$; range $0.4-7.0 \% ; n=14)$. Enumeration of the absolute number of memory $\mathrm{B}$ cells revealed an approximately 10-fold decrease when compared to that of controls. Thus, XLP patients had a statistically significant decrease in both the frequency and number of memory B cells $(P<0.001$; Figure 1B).

A reduction in memory $B$ cells was observed in XLP patients prior to EBV infection $\left(3.5 \% \pm 1.5 \%\right.$ in $\mathrm{EBV}^{-} \mathrm{XLP}$ patients; $\left.n=6\right)$ as well as after infection $(2.4 \% \pm 0.6 \% ; n=7)$, suggesting that the decrease in memory B cells results from altered SAP expression or function rather than exposure to EBV. To extend this observation, the memory B cell compartment of individuals diagnosed with acute EBV infection was examined. In these patients, the average frequency of B cells with a memory phenotype was $32.4 \% \pm 7.7 \%$ (range $11.5-44.8 \% ; n=4$ ), which was similar to that in healthy donors. Samples from XLP no. 11 both before and after EBV infection demonstrated a greater diminution of the memory B cell compartment following EBV infection (4.5\% before infection; $0.5 \%$ after infection). Thus, although the defect in generating memory $B$ cells is evident prior to EBV infection, the number of memory B cells may be further reduced following EBV infection.

Isotype-switched memory B cells do not develop in XLP patients. The human memory B cell population is heterogenous, comprising cells expressing IgM or those that have undergone class switching and express IgG, $\operatorname{IgA}$, or IgE (Figure $2 \mathrm{~A}$ and refs. 13, 29-33). In controls, $\mathrm{IgM}^{+}, \mathrm{IgG}^{+}$, tion (BMT) revealed a marked improvement in the frequency (i.e., $4.0 \%$ before BMT; $8.8 \%$ after BMT) and number of memory B cells, including those that have undergone isotype switching (i.e., approximately $9.0 \%$ before BMT; approximately $48 \%$ after BMT), thereby demonstrating the requirement for expression of SAP in hematopoietic cells for normal B cell differentiation.

$X L P B$ cells exhibit normal responses to T cell-dependent stimuli in vitro. SAP is expressed in human T cells (4-6) and GC B cells (34). Consequently, hypogammaglobulinemia in XLP could result from an intrinsic B cell defect, an extrinsic defect in events governing $\mathrm{T}$ cell-dependent $\mathrm{B}$ cell differentiation, or both. To determine whether XLP B cells are intrinsically defective, we compared the ability of normal and XLP naive B cells to undergo proliferation, isotype switching, and Ig secretion in vitro.

When CFSE profiles of CD40L-stimulated naive B cells from a healthy donor and an XLP patient were compared after 6 days of culture, it was found that a similar proportion of cells had undergone the same number of cell divisions, demonstrating a similar rate of proliferation (Figure 3A). Furthermore, proliferation of CD40L-stimulated naive B cells from the healthy donor and XLP patient was increased by the addition of IL-4, IL-10, or both, evidenced by detection of a greater proportion of cells in later divisions (Figure 3A). When 4 different controls and XLP patients were examined, the percentage of naive $B$ cells in each division was comparable for all culture conditions examined (Figure 3B).

Differentiation of naive B cells into effector cells is linked to cell division. For example, when stimulated with CD40L and IL-4, 
A

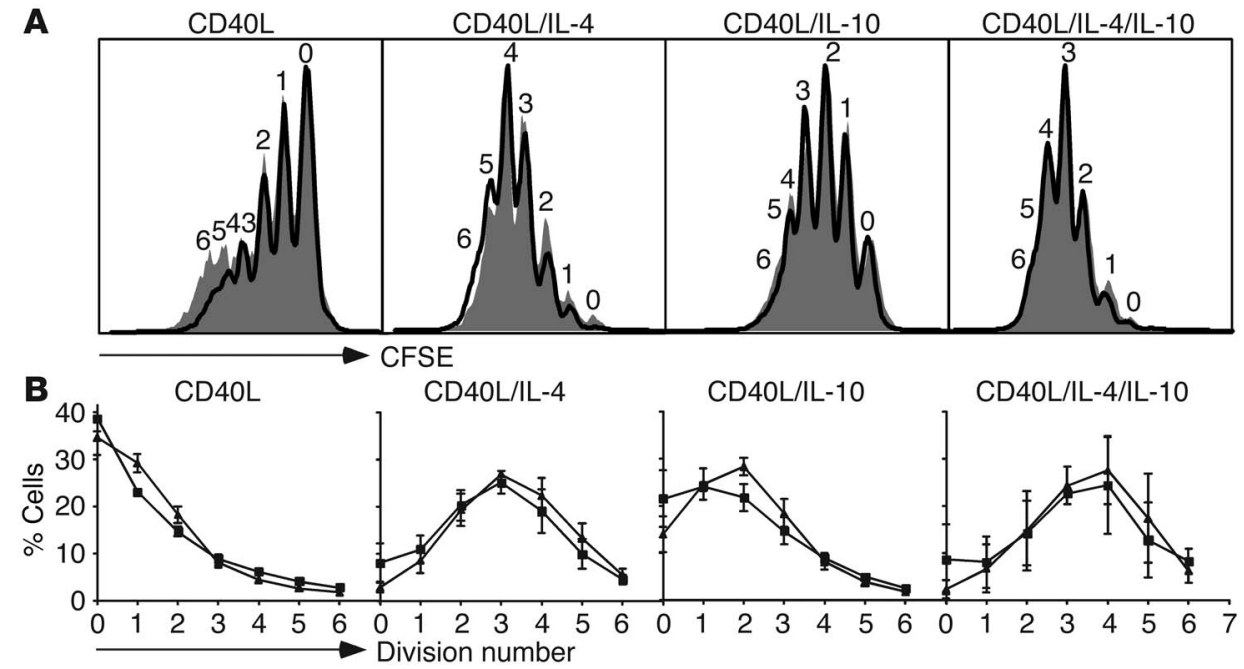

c
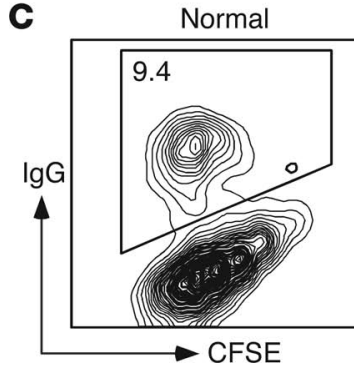

XLP no. 1

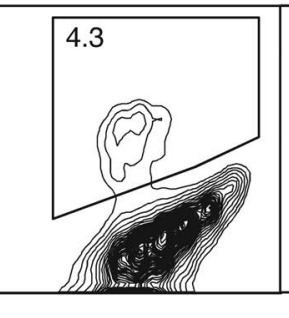

XLP no. 3

Figure 3

Naive B cells from XLP patients and healthy donors exhibit comparable proliferation and differentiation in response to T cell-dependent stimuli. Naive B cells were purified from healthy donors and XLP patients, labeled with CFSE, and cultured with CD40L in IL-4, IL-10, or IL-4 and IL-10 combined. (A) CFSE profiles from a representative healthy donor (solid histograms) and an XLP patient (XLP no. 8; open histograms) were determined after 6 days of culture. Values indicate the number of times the cells underwent division (i.e., division number). (B) By setting gates on CFSE peaks, the percentage of cells per division was determined (triangles, healthy donor; squares, XLP patient). The results represent the mean \pm SEM of experiments performed using naive $B$ cells isolated from 4 different healthy donors and 4 XLP patients (XLP nos. 1, 2, 3, and 8). (C) Naive B cells were labeled with CFSE and then cultured with CD40L and IL-4. After 6 days, cells were stained with anti-human IgG or an isotype control mAb to establish gates for $\mathrm{IgG}$ expression. The values in the contour plots represent the percentage of $\mathrm{IgG}^{+}$cells in the CD40L plus IL-4 cultures. No IgG ${ }^{+}$cells were detected in cultures performed in the absence of IL-4.

human and murine naive B cells acquire expression of IgG after 3 divisions $(33,35)$. Therefore, B cells from XLP patients were examined for their ability to differentiate in vitro and compared with $\mathrm{B}$ cells from healthy, SAP-sufficient donors. A similar percentage of $\mathrm{IgG}^{+}$cells was generated from normal and XLP naive B cells following culture with CD40L and IL-4 (Figure 3C). The range of $\mathrm{IgG}^{+}$cells observed for the stimulated XLP B cells was comparable to our previous observations using human naive $\mathrm{B}$ cells from different tissues (i.e., 3-15\%; ref. 33). This process occurred in a division-dependent manner, such that an increase in $\mathrm{IgG}^{+}$cells did not occur until the cells had undergone several rounds of cell division (Figure 3C). Consistent with the similar rates of differentiation of naive control and XLP B cells into $\mathrm{IgG}^{+}$cells, these cells secreted comparable amounts of $\operatorname{IgM}$ when cultured in vitro with CD40L alone (normal, $1.66 \pm 1.1 \mu \mathrm{g} / \mathrm{ml} ; \mathrm{XLP}, 2.3 \pm 1.25 \mu \mathrm{g} / \mathrm{ml}$; mean \pm SEM, $n=4$ ) or with IL-10 (normal, $10.0 \pm 5.7 \mu \mathrm{g} / \mathrm{ml}$; XLP, $7.2 \pm 3.5 \mu \mathrm{g} / \mathrm{ml})$. Furthermore, low amounts of $\operatorname{IgG}(24 \pm 6 \mathrm{ng} / \mathrm{ml})$ and $\operatorname{IgA}(237 \pm 152 \mathrm{ng} / \mathrm{ml} ; n=4)$ were detected when sort-purified naive XLP B cells were cultured with CD40L and IL-4 or CD40L and IL-10,
XLP no. 8

respectively; levels comparable to those of normal naive B cells (ref. 33 and data not shown). Taken together, these results demonstrate that XLP B cells are intrinsically normal, suggesting that hypogammaglobulinemia in XLP is attributable to defects extrinsic to the $\mathrm{B}$ cell.

Naive and memory $\mathrm{CD}^{+} \mathrm{T}$ cells develop normally in XLP patients but fail to provide $B$ cell help. We next investigated whether the observed in vivo defect in $B$ cell function was associated with a lack of $\mathrm{T}$ cell help, as suggested by previous studies of $\mathrm{SAP}^{-/-}$mice (18). The number of $\mathrm{CD}^{+} \mathrm{T}$ cells present in XLP patients was first determined. This analysis revealed that XLP patients had significantly reduced numbers of total $\mathrm{CD}^{+} \mathrm{T}$ cells compared with healthy SAPsufficient individuals (Figure 4A), confirming previous results (36). Adult PB CD4 ${ }^{+} \mathrm{T}$ cells consist of multiple subsets differing in their history of antigenic challenge (and therefore differentiation status). These subsets can be resolved by the differential expression of CD27 and CD45RA $(37,38)$. Expression of these molecules was used to determine whether the reduction in total $\mathrm{CD}^{+} \mathrm{T}$ cells in XLP resulted from a deficiency of either naive $\mathrm{T}$ cells $\left(\mathrm{CD} 45 \mathrm{RA}^{+} \mathrm{CD} 27^{+}\right)$, conventional memory $\mathrm{T}$ cells $\left(\mathrm{CD} 45 \mathrm{RA}^{-}\right.$ CD27 $\left.{ }^{+}\right)$, or effector memory $\mathrm{T}$ cells (CD45RA-CD27-) $(36,37)$. The frequencies of these different subsets of $\mathrm{CD}^{+} \mathrm{T}$ cells were comparable in healthy donors and XLP patients (Figure 4, B and C), which revealed that, although SAP deficiency does not impede differentiation of $\mathrm{CD}^{+} \mathrm{T}$ cells, there is a reduction in all $\mathrm{CD} 4^{+} \mathrm{T}$ cell subsets in XLP. The functionality of XLP CD4 ${ }^{+} \mathrm{T}$ cells was next investigated by coculturing anti-CD3 mAb-stimulated normal and XLP CD4 ${ }^{+} \mathrm{T}$ cells with naive allogeneic $B$ cells to examine their ability to provide the necessary signals to induce B cell activation and Ig production (39). When cocultured with naive allogeneic B cells, activated CD4+ $\mathrm{T}$ cells from healthy donors induced high levels of IgM secretion and low but detectable levels of IgG and IgA. In contrast, when $\mathrm{T}$ cells from XLP no. 2 were cocultured with allogeneic B cells under the same conditions, up to 20 -fold less Ig was produced, revealing a marked defect in $\mathrm{B}$ cell help (Figure 4D). This result was also observed when CD4 ${ }^{+} \mathrm{T}$ cells from XLP no. 1 and XLP no. 8 were examined (data not shown). Thus, although $\mathrm{CD} 4^{+} \mathrm{T}$ cells develop normally in the absence of SAP, their ability to induce $\mathrm{T}$ cell-dependent $\mathrm{B}$ cell differentiation is compromised.

$X L P C D 4^{+}$Tcells produce reduced amounts of IL-10. Defects in production of IL-4 have been previously reported in $\mathrm{SAP}^{-/-}$mice $(15,16)$. 

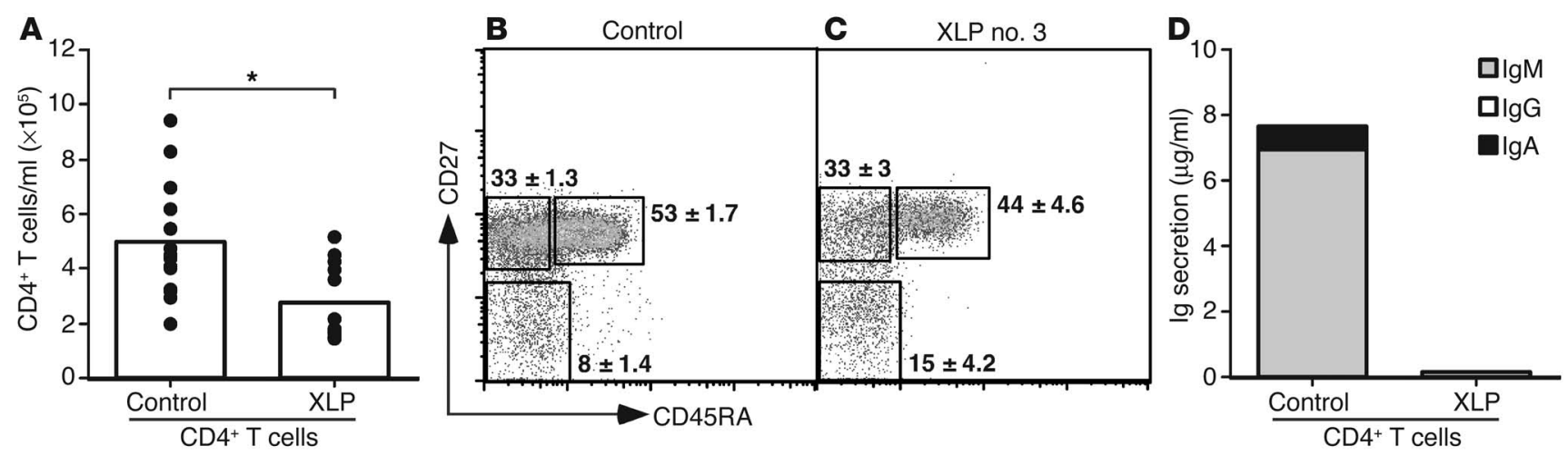

\section{Figure 4}

CD4 ${ }^{+} \mathrm{T}$ cells develop and differentiate normally in XLP; however, they are impaired in providing help for B cell differentiation. PBMCs from controls and XLP patients were labeled with mAbs specific for CD4, CD45RA, and CD27. (A) The absolute number of total CD4+ $T$ cells was calculated according to the frequencies of these cells in the different blood samples (control, $n=14 ; \mathrm{XLP}, n=12 ;{ }^{*} P<0.05$ ). (B and $\left.\mathbf{C}\right)$ The dot plots are from (B) 1 representative healthy donor and (C) 1 XLP patient (XLP no. 3), and the values represent the mean percentage \pm SEM of cells with the indicated surface phenotype; i.e., naive $\left(C D 45 R A^{+} C D 27^{+}\right)$, conventional memory $\left(C D 45 R^{-}{ }^{-} C D 27^{+}\right)$, or effector memory $\left(C D 45 R A^{-} C^{-} 27^{-}\right)$. (D) $\mathrm{CD}^{+} \mathrm{T}$ cells were isolated from a healthy donor or XLP no. 2 and then cocultured in triplicate with naive allogeneic $\mathrm{B}$ cells in the presence of immobilized anti-CD3 mAb. The levels of secreted IgM, IgG, and IgA were determined by ELISA after 12 days of culture.

Similarly, a recent study reported a reduction in the frequency of $\mathrm{CCR}^{+}$Th2-like memory CD4 ${ }^{+}$cells in 2 XLP patients; however, cytokine production by these cells was not examined (40). A defect in production of cytokines involved in regulating $\mathrm{B}$ cell function by human XLP CD $4^{+} \mathrm{T}$ cells could explain the inability of these cells to stimulate Ig production by B cells. Consequently, we investigated the production of IL- 4 and IL-10 by naive and conventional memory $\mathrm{CD}^{+} \mathrm{T}$ cells. Few $\mathrm{CD} 4^{+} \mathrm{T}$ cells expressed IL-4 or IL-10 in the absence of exogenous IL-4 (data not shown). However, IL-4- and IL-10-producing cells could be generated in the presence of exogenous IL-4 (Figure 5), consistent with previous studies (41). There was no significant difference in the frequency of IL-4-producing cells generated from normal and XLP naive and memory $\mathrm{CD}^{+} \mathrm{T}$ cells $(P>0.05$; Figure 5A). In contrast, the frequency of IL-10-producing naive and conventional memory $\mathrm{CD} 4^{+} \mathrm{T}$ cells was significantly reduced (mean, 2.6-fold) in all XLP patients examined compared to controls (Figure 5B). From examining CFSE-labeled $\mathrm{CD}^{+}{ }^{+} \mathrm{T}$ cells, it was evident that the majority of the IL-10-producing cells were found in the later cell divisions (Figure 5, C and D) and that the generation of IL-10-producing cells from both normal and XLP naive and memory CD4 ${ }^{+}$ $\mathrm{T}$ cells occurred in a division-linked manner (Figure 5E). However, there was a clear reduction in the frequency of IL $-10^{+}$cells generated from XLP naive and memory $\mathrm{CD}^{+} \mathrm{T}$ cells across all divisions when compared to normal cells (Figure 5E). A reduction in the ability of $\mathrm{XLP}$ naive and memory $\mathrm{CD}^{+} \mathrm{T}$ cells to differentiate into IL- $10^{+}$cells was observed in an XLP patient prior to EBV infection, as well as in $4 \mathrm{XLP}$ patients who were $\mathrm{EBV}^{+}$, suggesting that impaired differentiation of these cells was independent of EBV infection. Taken together, these results suggest that $\mathrm{CD}^{+} \mathrm{T}$ cells from XLP patients are defective in IL-10 production, which may account for the B cell phenotype present in these individuals.

Ectopic expression of SAP angments production of IL-10 by activated T cells. To examine the consequences of SAP expression on cytokine production, $\mathrm{CD}^{+} \mathrm{T}$ cell lines (TCLs) were generated from 2 healthy donors and 2 SAP-deficient XLP patients. These cell lines were transduced with a SAP-encoding retroviral vector in order to obtain ectopic expression of SAP. Western blot analysis indicated that purified transduced $\mathrm{CD}^{+}{ }^{+}$TCLs from healthy donors overexpressed SAP by approximately 2 -fold when compared to untransduced CD4 ${ }^{+}$TCLs whereas purified transduced CD4 ${ }^{+}$TCLs from the XLP patient showed partial restoration of SAP expression (data not shown). Following stimulation through CD3, the different TCLs produced detectable levels of IL-10 (Figure 6). Notably, production of IL-10 by 1 of the XLP CD4 ${ }^{+}$TCLs was approximately 5 -fold less than that of the 2 normal TCLs, demonstrating that the defect in IL-10 production observed in primary T cells could also be observed for some XLP CD4 ${ }^{+}$ TCLs (Figure 6). Overexpression or restoration, respectively, of SAP in normal or XLP CD4 ${ }^{+}$TCLs increased production of IL-10, such that the amount of IL-10 produced by the XLP CD4 ${ }^{+}$TCLs approximated that produced by normal CD4+ TCLs (Figure 6). Thus, IL-10 production can be augmented in the presence of increased levels of SAP.

$I L-10$ is required for $T$ cell-dependent $B$ cell differentiation. The failure of $\mathrm{XLPCD} 4+\mathrm{T}$ cells to provide B cell help in the coculture assay (Figure 4D) coupled with their reduced production of IL-10 (Figure 5, B-D) suggested that IL-10 produced by anti-CD3 mAb-stimulated normal $\mathrm{CD}^{+} \mathrm{T}$ cells drives Ig production by cocultured $\mathrm{B}$ cells. To test this possibility, we determined the effect of neutralizing IL-10 on Ig production in cocultures of normal $\mathrm{CD}^{+} \mathrm{T}$ cells and naive allogeneic $\mathrm{B}$ cells. The high level of Ig produced by naive B cells in the coculture system was reduced by more than $85 \%$ in the presence of an anti-IL-10 $\mathrm{mAb}$ while an isotype-control $\mathrm{mAb}$ had no effect (Figure 7A). The corollary of this finding is that the defective helper capability of $\mathrm{XLP} \mathrm{CD} 4^{+} \mathrm{T}$ cells could be rescued by the addition of IL-10 to these cocultures. Indeed, when cultures of activated XLP CD4 $4^{+} \mathrm{T}$ cells and naive $B$ cells were supplemented with exogenous IL-10, the amounts of IgM, IgG, and IgA produced were increased 3- to 10-fold (Figure 7, $\mathrm{B}-\mathrm{D})$. The increase in secretion of Ig induced by anti-CD3 mAbstimulated XLP CD4 ${ }^{+} \mathrm{T}$ cells in the presence of IL-10 improved the defect from being less than $10 \%$ of that induced by activated normal $\mathrm{CD}^{+} \mathrm{T}$ cells to approximately $50 \%$ (mean of 3 experiments; data not shown). Thus, decreased IL-10 production by XLP CD4 ${ }^{+} \mathrm{T}$ cells may significantly limit their ability to provide help to B cells.

To further explore the link between SAP expression and IL-10 production (as revealed in Figure 6), untransduced or SAP-transduced 
A
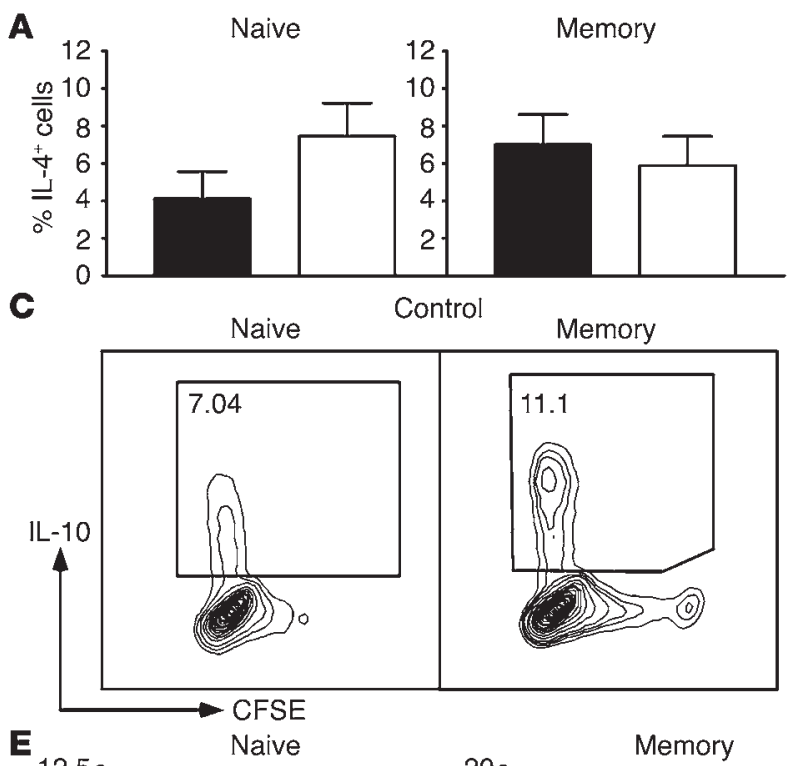
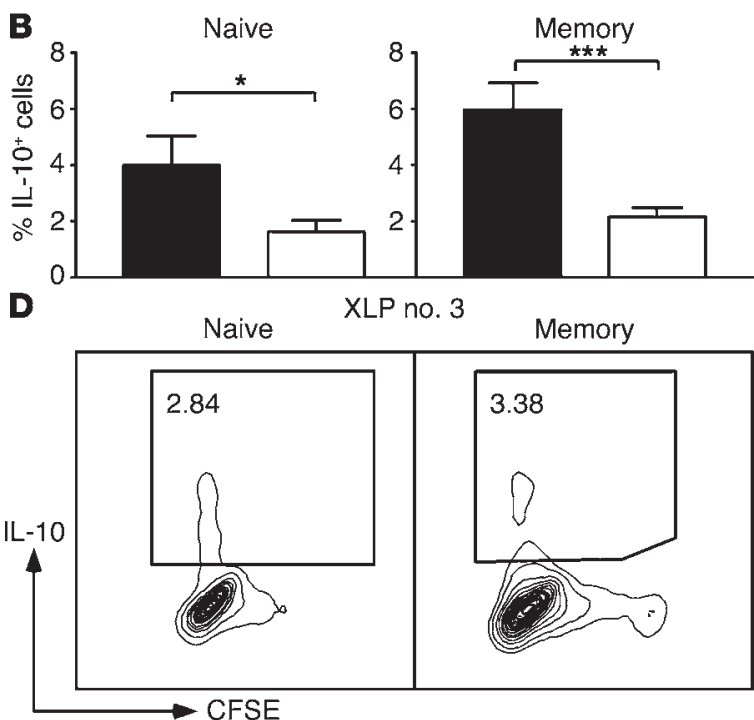

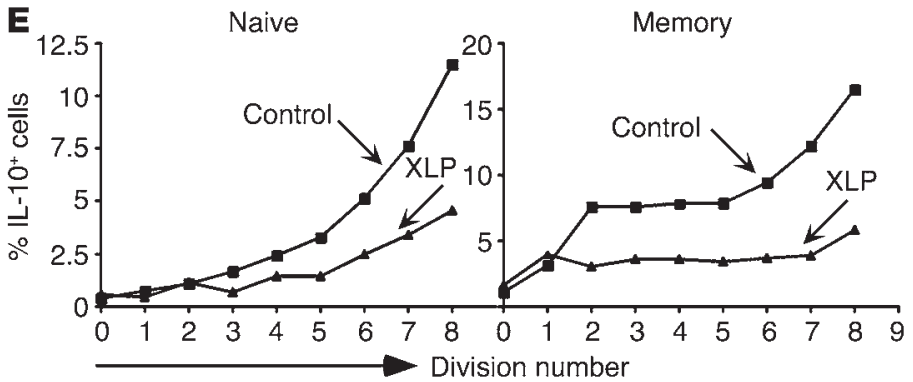

Figure 5

Reduced IL-10 production by naive and memory CD4 ${ }^{+} \mathrm{T}$ cells from XLP patients. (A and B) Purified CD4+ $\mathrm{T}$ cells were sorted into naive $\left(\mathrm{CD} 45 \mathrm{RA}^{+} \mathrm{CD} 27^{+}\right)$and conventional memory $\left(\mathrm{CD} 45 \mathrm{RA}^{-} \mathrm{CD} 27^{+}\right)$subsets, labeled with CFSE, and then cultured under Th2-type conditions as described in Methods. After a total of 6 or 7 days, the cells were harvested and restimulated with PMA and ionomycin to induce cytokine expression. Memory CD4+ T cells were also restimulated for cytokine production after either 4 or 5 days of primary culture or following an additional 2 days of reculture on day 6 or 7 . Following restimulation, cells were fixed with $4 \%$ formaldehyde and stained with mAbs specific for IL-4 (A), IL-10 (B), or an isotype control Ab (data not shown). The percentage of IL-4+ and IL-10+ CD4+ T cells from healthy donors (white bars) and XLP patients (black bars) was determined. Values represent the mean \pm SEM of 5-10 experiments performed using naive and conventional memory T cells isolated from 5 XLP patients (XLP nos. 1, 2, 3, 8, and 10). ${ }^{*} P<0.02$; ${ }^{* *} P<0.001$. (C and D) Contour plots of CFSE versus intracellular IL-10 expression by naive and conventional memory CD4+ $T$ cells from healthy donors (C) and XLP patients (D) show changes in IL-10 production with division. (E) The percentage of IL-10+ cells per division was determined by division slicing.

normal and $\mathrm{XLP} \mathrm{CD} 4{ }^{+}$TCLs were examined for their ability to induce Ig production by cocultured allogenic naive $\mathrm{B}$ cells. Consistent with the results obtained using primary $\mathrm{CD}^{+} \mathrm{T}$ cells (Figure 7, A-D), normal CD4 ${ }^{+}$TCLs induced secretion of high levels of all Ig isotypes by cocultured B cells, while XLP CD4+ TCLs failed to do so (Figure 7E). However, the ability of XLP CD4 ${ }^{+}$TCLs to provide B cell help was substantially improved following reconstitution of SAP expression. Thus, the level of Ig produced by B cells cocultured with SAP-transduced $\mathrm{XLP} \mathrm{CD}^{+}{ }^{+} \mathrm{TCL}$ was approximately $75 \%$ of that induced by normal CD4 ${ }^{+}$TCLs (Figure 7E). Interestingly, overexpression of SAP in normal $\mathrm{CD}^{+} \mathrm{T}$ cells also enhanced their ability to provide help to cocultured B cells (Figure 7E), demonstrating that T cell-dependent B cell activation can be modulated by differential expression of SAP.

SAP-mediated provision of T cell help is IL-10 dependent. The increase in B cell help afforded by ectopic expression of SAP (Figure 7E) was comparable to the increase in IL-10 production by $\mathrm{CD} 4^{+} \mathrm{TCLs}$ (Figure 6). Furthermore, the addition of exogenous IL-10 to cocultures of XLP $\mathrm{CD}^{+}$TCLs and B cells induced Ig production to an extent similar to that of cultures of SAP-transduced XLP CD4 $4^{+}$TCLs and B cells
(Figure 7F). These results suggest that the increase in B cell help due to the overexpression of SAP was caused by the increase in IL-10 production by $\mathrm{CD}^{+}$TCLs. This was confirmed by the demonstration that the addition of neutralizing anti-IL-10 mAb to cocultures of SAP-transduced XLP CD4 $4^{+}$TCLs and B cells reduced Ig production by approximately $80 \%$. Thus, SAP regulates $\mathrm{T}$ cell-dependent $B$ cell differentiation in an IL-10-dependent manner.

Decreased ICOS expression by XLP CD4 $4^{+} T$ cells. The amount of B cell help achieved following SAP-tranduction of XLP CD4 ${ }^{+}$TCLs or the addition of IL-10 to XLP CD4 $4^{+} \mathrm{T}$ cells was less than that of normal $\mathrm{CD}^{+} \mathrm{T}$ cells (Figure $7, \mathrm{~B}-\mathrm{F}$ ), thus suggesting additional defect(s) in $\mathrm{XLPCD} 4^{+} \mathrm{T}$ cells. We noticed many similarities in the phenotypes of mice and humans deficient in either SAP $(1-3,15,16,18)$ or ICOS/ ICOS ligand (ICOS/ICOS-L; reviewed in ref. 42). This raised the possibility that a defect in the ICOS pathway may also contribute to impaired T cell-dependent B cell help in XLP, especially given the role of ICOS in inducing IL-10 production by $\mathrm{CD}^{+} \mathrm{T}$ cells (23).

To investigate this, we examined ICOS expression on XLP $\mathrm{CD}^{+} \mathrm{T}$ cells following in vitro stimulation. The level of ICOS on 


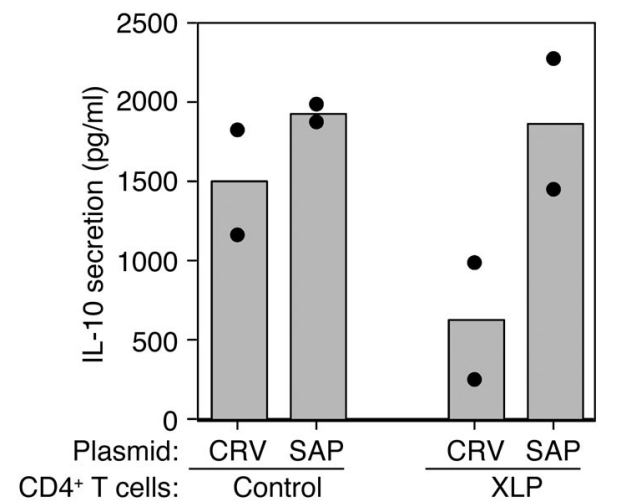

unstimulated normal and XLP CD4 ${ }^{+} \mathrm{T}$ cells was similar (Figure 8A). Following stimulation, ICOS expression was upregulated on the majority of normal CD4 ${ }^{+} \mathrm{T}$ cells (Figure 8, B and C; $76.3 \% \pm 2.2 \%$, $n=12$ ). In contrast, significantly fewer $\mathrm{XLPCD} 4^{+} \mathrm{T}$ cells upregulated ICOS (Figure 8, B and C; 44.5\% $\pm 4.3 \%, n=10 ; P<0.001$ ). This reduc-

\section{Figure 6}

Overexpression of SAP increases IL-10 production by CD4+ TCLs. Untransformed CD4+ $T$ cells from 2 healthy donors and 2 XLP patients (XLP nos. 3 and 17) were expanded in vitro with allogeneic feeder cells to obtain polyclonal lines. These CD4+ TCLs were transduced with either a control retroviral vector (CRV) or 1 encoding SAP. Transduced cells were purified and then stimulated with immobilized anti-CD3 mAbs $(1 \mu \mathrm{g} / \mathrm{ml})$, and the amount of IL-10 produced was determined after 48 hours. Each filled circle represents IL-10 production by the indicated $\mathrm{TCL}$; the column represents the mean. Values are representative of 2 independent experiments performed using these TCLs.

tion was not due to differences in stimulation, as the levels of expression of other activation molecules (CD69, CD95, CD154) were comparable between normal and XLP CD4 ${ }^{+} \mathrm{T}$ cells (data not shown). Furthermore, analysis over a 48-hour period revealed consistently lower ICOS expression by XLP CD4 ${ }^{+} \mathrm{T}$ cells compared with that of normal $\mathrm{CD}^{+} \mathrm{T}$ cells (data not shown). In contrast, the majority of $\mathrm{CD}^{+} \mathrm{T}$ cells from CVID patients upregulated ICOS to an extent similar to that of $\mathrm{CD}^{+} \mathrm{T}$ cells from healthy donors following in vitro
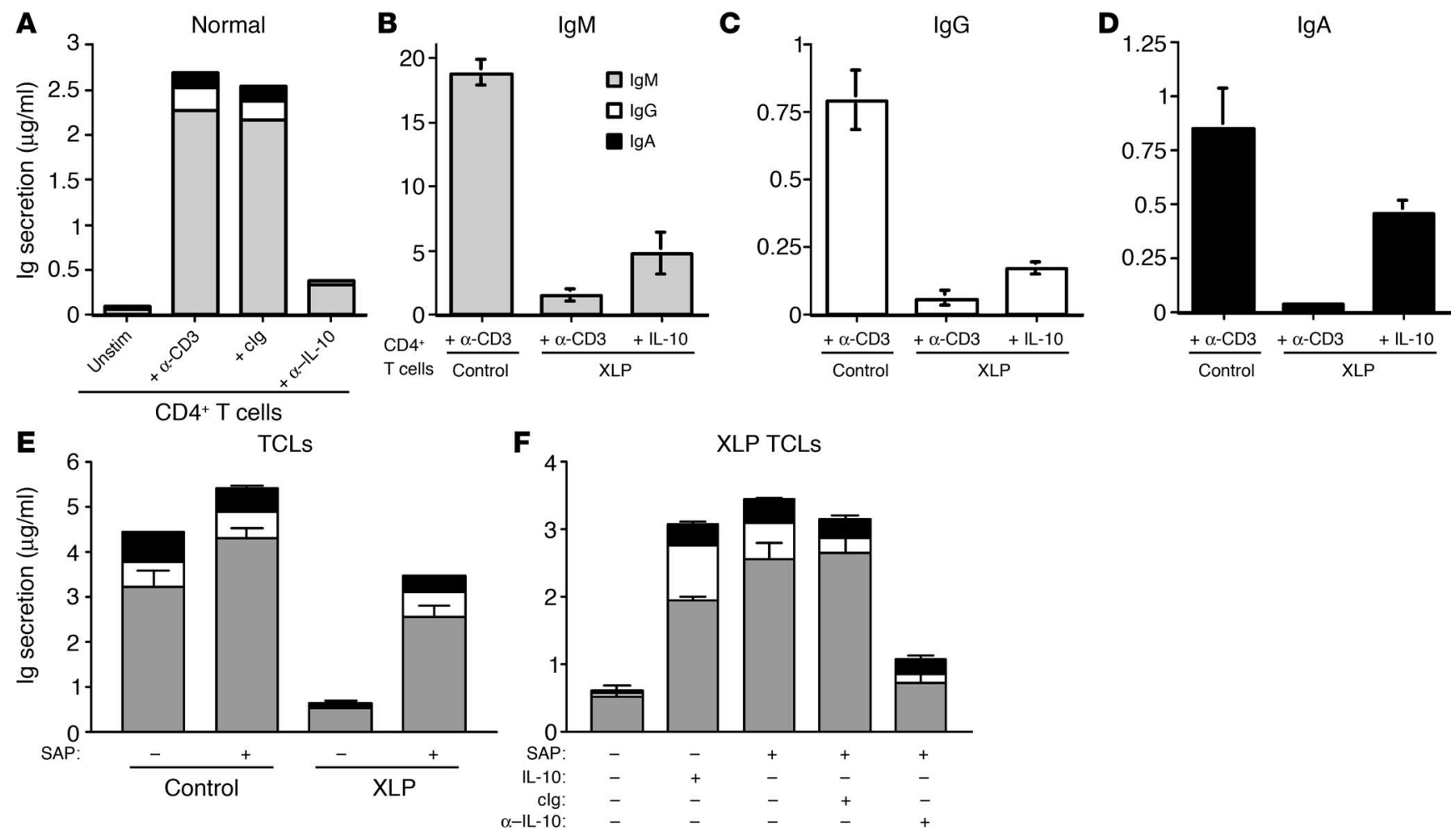

Figure 7

Defective T cell help in XLP is improved by exogenous IL-10. (A) Control CD4+ T cells were cocultured with naive allogeneic splenic B cells alone (unstim), or with immobilized anti-CD3 mAb $(+\alpha-C D 3 ; 5 \mu \mathrm{g} / \mathrm{ml})$ with or without control Ab (+ clg; $25 \mu \mathrm{g} / \mathrm{ml})$, or neutralizing anti-IL-10 mAb (+ $\alpha-I \mathrm{~L}-10$; $25 \mu \mathrm{g} / \mathrm{ml}$ ). After 12 days, supernatants were harvested and the amount of secreted IgM (gray bars), IgG (white bars), and IgA (black bars) was determined by ELISA. Values represent the means of quadruplicate culture. Similar results were obtained in additional independent experiments. (B-D) Control or XLP (XLP no. 2) CD4+ T cells were cocultured with B cells with immobilized anti-CD3 mAbs (+ $\alpha$-CD3). IL-10 was added to cultures containing B cells and XLP CD4+ T cells (+ IL-10; $100 \mathrm{U} / \mathrm{ml})$. After 12 days, supernatants were harvested and the amount of secreted lgM (B), $\lg G(C)$, and $\lg A(D)$ was determined by ELISA. The values represent the means of quadruplicate wells and are representative of 3 experiments performed using CD4 ${ }^{+} T$ cells from different XLP patients. (E) Control and XLP CD4+ TCLs (XLP no. 17) that were either untransduced (-) or SAPtransduced $(+)$ were cocultured with naive B cells in the presence of immobilized anti-CD3 mAb $(1 \mu \mathrm{g} / \mathrm{ml})$. (F) Untransduced or SAP-transduced XLP CD4+ TCLs were cocultured with B cells and immobilized anti-CD3 mAbs in the absence or presence of IL-10, control Ig (clg), or neutralizing anti-IL-10 mAb ( $\alpha-I L-10)$, as indicated. (E and F) Supernatants were harvested after 10 days and the amount of secreted IgM (gray bars), IgG (white bars), and IgA (black bars) was determined by ELISA. Values represent the means \pm SEM of triplicate cultures. 
A

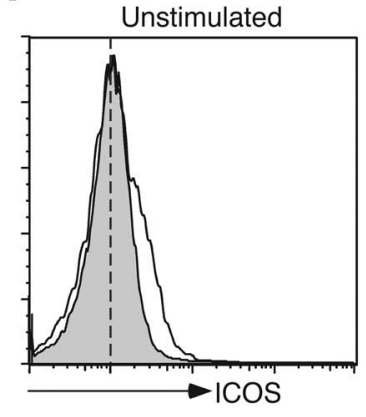

B

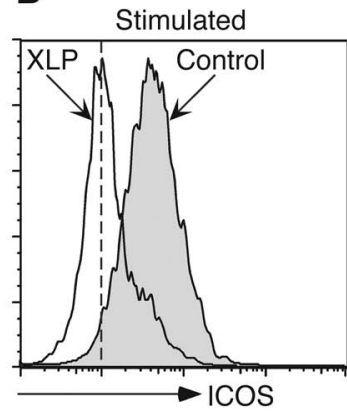

C

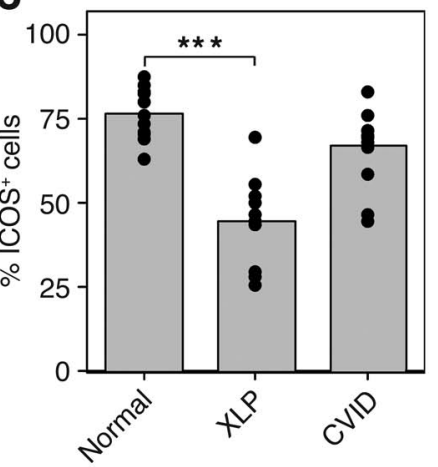

Figure 8

Impaired B cell differentiation in XLP is associated with reduced expression of ICOS by CD4+ $T$ cells. PBMCs from a healthy donor and XLP no. 1 were unstimulated (A) or cultured with PHA and IL-2 (stimulated; B). After 24 hours, the cells were harvested and stained with mAb specific for CD4 and ICOS. The induction of ICOS expression on CD4+ T cells from the healthy donor (solid histograms) and XLP no. 1 (open histograms) was determined by gates set on unstimulated cells. (C) Using the same method as outlined in $\mathbf{B}$, we investigated the induction of ICOS on CD4+ $\mathrm{T}$ cells from 12 controls, 8 XLP patients (XLP nos. 1, 2, 3, 4, 7, 8, 10, and 15), and 12 CVID patients. ICOS expression on CD4+ $\mathrm{T}$ cells isolated from XLP no. 1 and XLP no. 3 was determined on 2 separate occasions with 2 different healthy donors. ${ }^{* * *} P<0.001$.

stimulation (Figure 8C). Thus, decreased expression of ICOS on XLP $\mathrm{CD}^{+} \mathrm{T}$ cells may be another mechanism, in addition to reduced IL-10 production, that contributes to impaired T cell help in XLP.

Th1 cytokine production by naive and memory XLP CD4 $4^{+}$cells is normal. It also seemed possible that reduced Ig production by XLP B cells in vivo may have resulted from increased production of IFN- $\gamma$, which can inhibit Ig secretion (43). This would be consistent with the finding of increased IFN- $\gamma$ production by $\mathrm{CD} 4^{+} \mathrm{T}$ cells from $\mathrm{SAP}^{-/-}$mice $(15,16,44,45)$. However, production of IFN- $\gamma$, as well as TNF- $\alpha$, IL-2, and GM-CSF by naive and conventional memory $\mathrm{CD}^{+} \mathrm{T}$ cells from healthy donors and XLP patients was equivalent when cultured in the presence (Table 2) or absence (data not shown) of exogenous IL-12 in order to induce differentiation to Th1-type cells (41). These results suggest that production of Th1-type cytokines by human $\mathrm{CD}^{+} \mathrm{T}$ cells is not impaired in the absence of functional SAP and that the B cell phenotype in XLP more likely results from impaired production of IL-10.

\section{Discussion}

Recent studies have suggested that reduced long-term humoral immunity in $\mathrm{SAP}^{-/-}$mice results from a defect in $\mathrm{CD}^{+} \mathrm{T}$ cells (18), although the underlying mechanism has not been elucidated. The demonstration of SAP expression in human GC B cells (34), as well as in T cells (4-6), raised the possibility that aberrant humoral immunity in XLP may result from defects in T cells, B cells, or both. We investigated the consequences of reduced SAP expression on $\mathrm{B}$ and $T$ cell differentiation in 14 XLP patients from 9 different families. XLP patients displayed normal frequencies and numbers of PB B cells (Figure 1A), consistent with previous studies (36), suggesting SAP does not play a role in the generation of mature B cells. However, irrespective of the SH2D1A mutation, the majority of $\mathrm{B}$ cells in XLP patients were naive, indicating a severe reduction in memory B cells, especially isotype-switched cells (Figure 1B and Figure 2). This defect was observed in patients independently of EBV infection, suggesting the decrease in memory B cells results from altered SAP function. This parallels the reduced basal levels that the generation of memory B cells

of some serum Ig isotypes observed in XLP patients prior to EBV infection (46) as well as in uninfected $\mathrm{SAP}^{-/-}$mice $(15,17)$. However, there tended to be a further decrease in the frequency of memory B cells following EBV infection, again mirroring the progressive decline in serum Ig levels in $\mathrm{EBV}^{+} \mathrm{XLP}$ patients $(1,40)$ and infected SAP $-/$ - mice (17). Our results support a recent study that reported reduced numbers of total memory B cells in 2 related XLP patients during EBV infection (40). However, this study also found reduced numbers of total B cells, in contrast to our data and data published previously (36), suggesting additional factors may affect B cell numbers in this 1 family (40). Despite this difference, the absence of memory $\mathrm{B}$ cells is consistent with the inability of XLP patients to generate switched Ig isotypes following immunization with T cell-dependent Ag (47). The finding was impaired in all XLP patients examined strongly supports the universal use of replacement Ig as a therapy for this disease. In contrast to XLP patients, CVID patients showed a broad range of memory B cell phenotypes, with variable defects in isotype switching (Figures 1 and 2; refs. 21, 22). This not only highlights the heterogeneity in the presentation of CVID but demonstrates that therapeutic Ig administered to XLP and CVID patients does not contribute to the specific reduction in memory B cells in XLP.

By analyzing the response of XLP B cells to T cell-dependent stimuli in vitro, it became apparent that these cells were intrinsically normal, similar to those of $\mathrm{SAP}^{-/-}$mice, which can mount normal T-independent responses (19). Thus, defective Ig production by XLP B cells in vivo is likely to be due to non-B cell autonomous defects. $\mathrm{CD}^{+} \mathrm{T}$ cells were examined to delineate the nature of such defects. Production of IL- 2 , IFN- $\gamma$, and TNF- $\alpha$ by normal and XLP naive and memory CD $4^{+} \mathrm{T}$ cells was similar (Table 2 ). We also observed comparable production of IFN- $\gamma$ and IL- 2 by stimulated normal and XLP CD4 ${ }^{+}$TCLs (data not shown). These results contrast with studies of $\mathrm{SAP}^{-/-}$mice, which have reported increased IFN- $\gamma$ by SAP-deficient CD $4^{+} \mathrm{T}$ cells $(15,16,18,44,45)$.

When we analyzed production of cytokines known to play important roles in humoral immunity, we found that similar frequencies of IL-4-producing cells could be generated in vitro from XLP and normal CD4 ${ }^{+} \mathrm{T}$ cells. In contrast, the ability of both naive and memory XLP CD4 ${ }^{+} \mathrm{T}$ cells to differentiate into IL-10-producing cells was significantly reduced (Figure 5). The finding that XLP CD4 $4^{+} \mathrm{T}$ cells exhibit reduced production of IL-10 prior to EBV infection is consistent with our observation that the memory B cell compartment is severely contracted in all XLP patients, irrespective of their EBV status. The deficit in IL-10 production by XLP CD4 ${ }^{+} \mathrm{T}$ cells may also contribute to the susceptibility of these patients to EBV infection since an association has been observed between a polymorphism in the promoter of the human $I L-10$ gene that results in increased IL-10 secretion and resistance to EBV infection (48).

$\mathrm{SAP}^{-/-}$mice were also reported to have defects in both IL-4 and IL-10 production (16). However, the IL-10 deficiency could be corrected by 


\section{Table 2}

CD4+ XLP T cells yield frequencies of Th1 cytokine-expressing cells similar to those of control CD4+ T cells

\begin{tabular}{lcccccccc}
\multicolumn{8}{c}{ \% Cytokine-expressing cells } \\
Cytokines & Control & No. exp. & XLP & No. exp. & Control & No. exp. & XLP & No. exp. \\
IL-2 & $44.7 \pm 4.9$ & 9 & $50.8 \pm 7.2$ & 6 & $40.8 \pm 5.5$ & 7 & $36.8 \pm 5.1$ & 7 \\
& $(24.8-65.4)$ & & $(21.9-71.4)$ & & $(19-54.4)$ & & $(22.3-60)$ & \\
IFN- $\gamma$ & $24.8 \pm 5.6$ & 9 & $31.2 \pm 6.6$ & 6 & $30.1 \pm 4.2$ & 7 & $31.0 \pm 5.1$ & 7 \\
& $(1-50.6)$ & & $(0.7-40.1)$ & & $(9.5-41.9)$ & & $(8.9-46.4)$ & \\
TNF- $\alpha$ & $41.4 \pm 7.5$ & 9 & $48.0 \pm 9.5$ & 6 & $55.3 \pm 5.7$ & 7 & $59.1 \pm 4.0$ & 7 \\
& $(4.2-72.1)$ & & $(2.7-67.5)$ & & $(25.8-72.8)$ & & $(48.7-75.1)$ & \\
GM-CSF & $20.7 \pm 5.8$ & 7 & $24.9 \pm 4.9$ & 6 & $28.3 \pm 4.9$ & 7 & $39.4 \pm 3.9$ & 7 \\
& $(1.8-38.3)$ & & $(1.4-34.4)$ & & $(8-45.6)$ & & $(29.2-53.5)$ &
\end{tabular}

Naive and conventional memory CD4+ $\mathrm{T}$ cells were isolated from healthy donors and XLP patients and then cultured with immobilized anti-CD3 and soluble anti-CD28 mAbs, IL-2, IL-12, and neutralizing antiIL-4 mAbs. After 5 days, cells were harvested and restimulated with PMA and ionomycin to induce cytokine expression. Cells were then fixed and stained for intracellular cytokine production using mAbs specific for IL-2, IFN- $\gamma$, TNF- $\alpha$, and GM-CSF. Data represent the mean percentage \pm SEM of cytokine-expressing cells for up to 9 healthy donors and experiments using CD4 ${ }^{+} T$ cells from 5 XLP patients (XLP nos. 1, 2, 3, 8, and 10), some of which were examined on multiple occasions. The range of cytokine-producing cells is indicated in parentheses. no. exp., number of experiments.

exogenous IL-4, which demonstrates that the reduced production of IL-10 resulted from the inability of $\mathrm{SAP}^{-/-}$murine $\mathrm{CD}^{+} \mathrm{T}$ cells to secrete IL-4 (45). In contrast, the deficiency in IL-10 production by $\mathrm{XLPCD}^{+} \mathrm{T}$ cells could not be overcome by exogenous IL-4 (Figure 5), indicating a requirement for SAP in the differentiation of $\mathrm{CD}^{+} \mathrm{T}$ cells into IL-10-producing cells. This is consistent with our finding that overexpression of wild-type SAP in normal and XLP CD $4^{+}$TCLs improved or restored IL-10 production by these cells (Figure 6) but had minimal effect on IL-4 production by normal $\mathrm{CD}^{+} \mathrm{T}$ cells (data not shown). Extrapolating from recent studies detailing the effect of different doses of IL-2 on T cell proliferation (49), it is likely that an approximately 2 - to 5 -fold reduction in the frequency of IL- $10^{+} \mathrm{T}$ cells would have large (greater than 10-fold) effects on the behavior of IL-10 responsive cells, namely B cells. Indeed, the significance of impaired IL-10 production by XLP CD4 ${ }^{+} \mathrm{T}$ cells was underscored by the finding that their ability to provide help for Ig production by $\mathrm{B}$ cells could be significantly enhanced by either the addition of exogenous IL-10 or the reconstitution of SAP expression by retroviralmediated gene transfer. Strikingly, the improved B cell response in the presence of SAP-transduced XLP CD4+ TCLs was IL-10 dependent (Figure 7F). This demonstrates a direct link between the expression of SAP by $\mathrm{CD}^{+} \mathrm{T}$ cells and IL-10 production, thereby elucidating a mechanism by which SAP regulates T cell-dependent B cell activation. These findings are consistent with the well-described ability of IL-10 to act as a growth, differentiation, and Ig isotype switch factor for human B cells $(24,25,50)$. Overall, the identification of reduced IL-10 production by $\mathrm{CD} 4{ }^{+} \mathrm{SAP}-$ deficient $\mathrm{T}$ cells raises the prospect of devising IL-10-based therapies for the treatment of XLP.

Although exogenous IL-10 or reconstitution of SAP expression improved the helper function of XLP CD4 ${ }^{+} \mathrm{T}$ cells, neither completely restored it to the levels of SAP-sufficient CD $4^{+} \mathrm{T}$ cells (Figure 7). This suggests the existence of additional defects in XLP CD4 ${ }^{+} \mathrm{T}$ cells. A potentially important difference that we observed between healthy individuals and XLP patients was the reduced expression of ICOS on SAP-deficient $\mathrm{CD}^{+} \mathrm{T}$ cells following in vitro activation (Figure 8). A major function of ICOS is the preferential induction of IL-10

\section{Methods}

production by activated $\mathrm{CD}^{+} \mathrm{T}$ cells $(23,42)$. Interestingly, there are many similarities between humans and mice that are deficient in SAP and ICOS or its ICOS-L, such as the inability to form GCs and to undergo Ig isotype switching in vivo, a deficiency in memory $B$ cells and plasma cells, and reduced production of IL- 4 and IL-10 by CD $4^{+}$ T cells $(15,16,18,42)$. It is clear from these studies that both ICOS and SAP are critical for productive and appropriate humoral immunity. It is therefore tempting to speculate that they are components of a common pathway. Several additional lines of evidence also support this proposal. First, both $\mathrm{ICOS}^{-/-}$and $\mathrm{SAP}^{-/-} \mathrm{T}$ cells are impaired in their ability to produce IL-4 and, because of this, exhibit defects in inducing expression of transcription factors (c-maf, GATA-3) involved in eliciting a Th2 response $(44,45,51)$. Second, ICOS has been found to be overexpressed on $\mathrm{CD}^{+} \mathrm{T}$ cells in human and murine SLE $(52,53)$; conversely, deficiency of ICOS or SAP protects against the development of murine SLE and other autoimmune diseases $(19,42)$. Third, expression of ICOS, SAP, and the SAP-associating receptors CD84 and Ly9 is greatly increased on follicular $\mathrm{T}$ helper cells ( $\mathrm{T}_{\mathrm{FH}}$ cells), which localize to GCs in human lymphoid tissues $(23,54,55)$. $\mathrm{T}_{\mathrm{FH}}$ cells are likely to be involved in regulating the differentiation of GC B cells into memory and plasma cells because they produce high levels of IL-10 (55) and IL-21 (54), another cytokine that potently induces B cell differentiation $(56,57)$, and efficiently induce B cells to secrete Ig in vitro (55). Thus, it is possible that secretion of B cell helper cytokines such as IL-10 and IL-21 by $\mathrm{T}_{\mathrm{FH}}$ cells, as well as expression of ICOS on these cells, is regulated by the SAP-signaling pathway elicited by homotypic interactions between SAP-associating receptors (SLAM, CD84, Ly9) expressed on $T_{F H}$ cells and memory B cells $(13,29,54)$. In the presence of inactivating mutations in $S H 2 D 1 A$, these processes would be impaired. Interestingly, expression of ICOS on murine $\mathrm{CD} 4^{+} \mathrm{T}$ cells can be modulated by ectopic expression of GATA- 3 or IL-4 (58). Because SAP $-/-\mathrm{CD}^{+} \mathrm{T}$ cells exhibit impaired production of IL-4 as well as activation of GATA-3 $(44,45)$, it is possible that ICOS expression by murine $\mathrm{CD}^{+} \mathrm{T}$ cells is also reduced in the absence of SAP. Therefore, compromised production of B cell tropic cytokines (mouse, IL-4; human, IL-10), coupled with reduced expression of ICOS could potentially provide a mechanism for impaired humoral immunity in $\mathrm{SAP}^{-/-}$mice as well as XLP patients.

Reagents. Streptavidin-tricolor (SA-TC), allophycocyanin-conjugated (APCconjugated) anti-CD4, and anti-IFN- $\gamma$ mAbs were from CALTAG Laboratories. SA-peridinin chlorophyll (SA-PerCp), FITC-conjugated anti-CD20, biotinylated anti-CD45RA, anti-IgD, anti-IgM, anti-IgG, anti-IgA, anti-TNF- $\alpha$, anti-GM-CSF, PE-conjugated anti-CD27, anti-CD154, anti-IL-2, anti-IL-4, anti-IL-10, unconjugated anti-CD28 mAb (CD28.2), anti-IFN- $\gamma$ (B27), and anti-IL-4 (MP4-25D2) mAbs were from BD Biosciences - Pharmingen. Biotinylated anti-ICOS $\mathrm{mAb}$ was purchased from eBioscience. Unconjugated and biotinylated goat anti-human IgM, IgG, or IgA polyclonal antisera were 
purchased from SouthernBiotech. Recombinant human CD40L (33) was a generous gift from Marilyn Kehry (Boehringer Ingleheim, Ridgefield, Connecticut, USA). Recombinant human IL-2 (rIL-2) was purchased from Chemicon; anti-CD3 mAb (Spv-T3b) was provided by Hergen Spits (Netherlands Cancer Institute, Amsterdam, The Netherlands) (59), human rIL-4, rIL-10, and neutralizing anti-IL-10 mAb were provided by Rene de Waal Malefyt (DNAX Research Institute, Palo Alto, California, USA). Recombinant mouse IL-12 was from R\&D Systems. CFSE and phytohemagglutinin (PHA) were purchased from Invitrogen Corp. and Sigma-Aldrich, respectively.

Isolation and characterisation of PBMC. PB samples were collected from healthy donors, XLP and CVID patients, and EBV-infected individuals following informed consent, and PBMCs were isolated by Ficoll-Paque centrifugation. All studies described were approved by the Central Sydney Area Health Service Human Research Ethics Committee, and the Children's Hospital of Philadelphia Institutional Review Board. PBMCs were surface stained with $\mathrm{mAb}$ to characterize B cell subsets as described $(13,33)$. Data was collected on a FACScalibur flow cytometer (BD Biosciences - Immunocytometry Systems) and analyzed using FlowJo software (Tree Star Inc.).

Isolation of $\mathrm{B}$ and $T$ cells. $\mathrm{CD} 19^{+} \mathrm{B}$ cells and $\mathrm{CD} 4^{+} \mathrm{T}$ cells were isolated from PBMC using the CD19- and CD4-DYNA/detach-a-bead systems, respectively (Dynal Biotech). Naive B cells were then isolated using CD27 MACS Microbeads (Miltenyi Biotec) or by sorting CD20 ${ }^{+} \mathrm{CD} 27^{-}$cells $(29,33)$. $\mathrm{CD}^{+} \mathrm{T}$ subsets were isolated by labeling with $\mathrm{PE}-$ anti-CD27 and biotin-anti-CD45RA mAbs, followed by SA-TC, and sorting CD45RA ${ }^{+} \mathrm{CD} 27^{+}$ (naive) and $\mathrm{CD}^{-} 4 \mathrm{RA}^{-} \mathrm{CD} 27^{+}$(conventional memory) subsets $(37,38)$ using a FACStar Plus or FACSVantage cell sorter (BD). Purified human B and T cells were then labelled with CFSE (33).

$B$ cell cultures. CFSE-labelled naive B cells $\left(2 \times 10^{5} / 500 \mu \mathrm{l}\right)$ were cultured for 6 days in 48-well plates (BD Biosciences - Discovery Labware) with CD40L alone or in the presence of rIL-4 $(400 \mathrm{U} / \mathrm{ml})$, rIL-10 $(100 \mathrm{U} / \mathrm{ml})$, or both. In vitro-activated naive B cells were harvested and surface stained for expression of Ig isotypes (33). The levels of secreted Ig in culture supernatants were determined using specific ELISA (33).

T cell cultures. CFSE-labelled CD4 ${ }^{+} \mathrm{T}$ cells were cultured in 48-well plates $\left(2 \times 10^{5} / 500 \mu \mathrm{l}\right)$ with immobilized anti-CD3 $\mathrm{mAb}(5 \mu \mathrm{g} / \mathrm{ml})$, anti-CD28 $\mathrm{mAb}$ $(750 \mathrm{ng} / \mathrm{ml}), \mathrm{rIL}-2(20 \mathrm{U} / \mathrm{ml})$, and either rIL-4 $(100 \mathrm{U} / \mathrm{ml})$ and neutralizing anti-IFN- $\gamma(5 \mu \mathrm{g} / \mathrm{ml}$; Th2 culture $)$ or rIL-12 $(1 \mathrm{ng} / \mathrm{ml})$ and neutralizing antiIL-4 $(5 \mu \mathrm{g} / \mathrm{ml}$; Th1 culture; ref. 41$)$. After 4 or 5 days, CD $4{ }^{+} \mathrm{T}$ cells from the Th1 culture were harvested and restimulated for 6 hours with PMA $(100 \mathrm{ng} / \mathrm{ml}$; Sigma-Aldrich) and ionomycin $(750 \mathrm{ng} / \mathrm{ml}$; Sigma-Aldrich), with Brefeldin A ( $5 \mu \mathrm{g} / \mathrm{ml}$; Sigma-Aldrich) added after 2 hours. After this time, cells were fixed in $4 \%$ formaldehyde (Sigma-Aldrich) and stained for expression of intracellular cytokines (IL-2, IFN- $\gamma$, TNF- $\alpha$, and GM-CSF). All Abs and wash steps were performed a in $0.5 \%$ saponin solution. For analysis of Th2 cytokines, cells were cultured for 4 or 5 days, harvested, washed, and subjected to a secondary culture in the presence of rIL-2, rIL-4, and anti-IFN- $\gamma$. Two days later, cells were harvested and restimulated for cytokine production with PMA and ionomycin as described above, and intracellular IL-4 and IL-10 expression was determined using specific mAbs.

Transduction of $\mathrm{CD} 4^{+} T$ cells. Untransformed CD4 ${ }^{+} \mathrm{TCLs}$ were generated by repeated allogeneic stimulations from 2 SAP-deficient XLP patients and from 2 healthy donors (7). A retroviral vector encoding SAP and the surface marker $\triangle$ NLGFR (60) was used to transduce the CD4 ${ }^{+}$TCLs after prestimulation with anti-CD3 mAbs (1 $\mu \mathrm{g} / \mathrm{ml}$ OKT3; Janssen-Cilag), soluble antiCD28 mAbs (1 $\mu \mathrm{g} / \mathrm{ml})$, IL-2 (100 IU/ml), and IL-7 (10 ng/ml). Transduced $\mathrm{T}$ cells were immunoselected with anti- $\triangle$ NLGFR $\mathrm{mAbs}$ and purified with rat anti-mouse IgG1-coated magnetic beads (Dynabeads M-450, Dynal Biotech). After 1 round of immunoselection, over $95 \%$ of the cells expressed the $\triangle$ LNGFR marker. Expression of SAP was verified by Western blot analysis using an anti-SAP rabbit polyclonal antibody $(14,26)$. IL-10 present in supernatants of cells that had been stimulated with $1 \mu \mathrm{g} / \mathrm{ml}$ of immobilized anti-CD3 mAb for 48 hours was measured by capture ELISA.

$B$ cell-T cell cocultures. B cell-T cell cocultures were performed as previously described (39). $\mathrm{CD} 4^{+} \mathrm{T}$ cells were isolated from healthy donors and XLP patients. Control and XLP CD4 $4^{+}$TCLs that were untransduced or transduced with SAP (as above) were expanded in 24-well plates containing irradiated PBMCs $\left(1 \times 10^{6} /\right.$ well $)$ and an EBV-transformed B cell line $\left(1 \times 10^{5} /\right.$ well $)$, PHA $(2 \mu \mathrm{g} / \mathrm{ml})$, and IL-2 $(20 \mathrm{U} / \mathrm{ml})$, as previously described (7). CD4 $4^{+} \mathrm{T}$ cells or TCLs were then treated with mitomycin C ( $40 \mu \mathrm{g} / \mathrm{ml}$; Sigma-Aldrich) for 1 hour at room temperature and then cultured $\left(1 \times 10^{5} /\right.$ well $)$ with allogeneic naive splenic B cells $\left(2.5 \times 10^{4}\right)$ in the absence or presence of immobilized anti-CD3 mAbs (CD4 ${ }^{+} \mathrm{T}$ cells, $5 \mu \mathrm{g} / \mathrm{ml}$; CD4 ${ }^{+}$TCLs, $1 \mu \mathrm{g} / \mathrm{ml}$ ), in 96-well U-bottom tissue culture plates. To neutralize endogenous IL-10, naive B cells were cultured with $\mathrm{CD} 4^{+} \mathrm{T}$ cells or TCLs in the presence of anti-IL-10 mAbs $(25 \mu \mathrm{g} / \mathrm{ml})$ or control Abs, which were added on day 0 and then after every 4 days of culture. Exogenous IL-10 $(100 \mathrm{U} / \mathrm{ml})$ was added to relevant cultures of $\mathrm{XLP} \mathrm{CD}^{+} \mathrm{T}$ cells/TCLs and naive B cells on day 0 . After 10-14 days of culture, supernatants were harvested and Ig production determined (33).

Determination of ICOS expression. PBMCs $\left(1 \times 10^{6} / \mathrm{ml}\right)$ were activated with PHA $(5 \mu \mathrm{g} / \mathrm{ml})$ and rIL-2 $(20 \mathrm{U} / \mathrm{ml})$. After 24 hours, cells were harvested and stained with APC-anti-CD4, and biotin-anti-ICOS or biotin-hamster IgG1 isotype control Ab followed by SA-PerCp. Expression of ICOS on $\mathrm{CD}^{+} \mathrm{T}$ cells was determined by analyzing the frequency of lymphocytes that were $\mathrm{CD} 4^{+} \mathrm{ICOS}^{+}$lymphocytes.

Statistics. All statistics were performed using Prism software (version 3.0 for Macintosh; GraphPad Software).

\section{Acknowledgments}

We thank Frank Alvaro, Ron Walls, Don Anderson, Sean Riminton, Maurizio Aricò, and Franco Locatelli for providing patient samples; Rene de Waal Malefyt and Marilyn Kehry for reagents; Danielle Avery, Vanessa Bryant, and Kim Good for providing naive B cells; and Tony Basten and Tri Phan for critical review of this manuscript. This work was supported by the National Health and Medical Research Council (NHMRC) of Australia and the New South Wales Cancer Council. C.S. Ma is the recipient of an Australian postgraduate award from the University of Sydney; K.E. Nichols is a recipient of a Junior Faculty Scholar Award from the American Society of Hematology and an award from the US Immunodeficiency Network (U01AI30070); L. Dupré, G. Andolfi, and M.-G. Roncarolo are supported by the Italian Telethon Foundation; P.D. Hodgkin is a Senior Research Fellow of the NHMRC; and S.G. Tangye is the recipient of an RD Wright Biomedical Career Development Award from the NHMRC.

Received for publication November 24, 2004, and accepted in revised form January 11, 2005.

Address correspondence to: Stuart Tangye, Centenary Institute of Cancer Medicine and Cell Biology, Locked Bag No. 6, Newtown 2042, New South Wales, Australia. Phone: 011-61-2-9565-6127; Fax: 011-61-2-9565-6103; E-mail: s.tangye@centenary.usyd.edu.au.
1. Seemayer, T.A., et al. 1995. X-linked lymphoproliferative disease: twenty-five years after the discovery.

Pediatr. Res. 38:471-478.

2. Morra, M., et al. 2001. X-linked lymphoproliferative disease: a progressive immunodeficiency. Annu. Rev. Immunol. 19:657-682.

3. Latour, S., and Veillette, A. 2004. The SAP family of adaptors in immune regulation. Semin.
Immunol. 16:409-419.

4. Sayos, J., et al. 1998. The X-linked lymphoproliferative-disease gene product SAP regulates signals induced through the co-receptor SLAM. 
Nature. 395:462-469.

5. Coffey, A.J., et al. 1998. Host response to EBV infection in X-linked lymphoproliferative disease results from mutations in an $\mathrm{SH} 2$-domain encoding gene. Nat. Genet. 20:129-135.

6. Nichols, K.E., et al. 1998. Inactivating mutations in an SH2 domain-encoding gene in X-linked lymphoproliferative syndrome. Proc. Natl. Acad. Sci. U. S. A. 95:13765-13770.

7. Cocks, B.G., et al. 1995. A novel receptor involved in T-cell activation. Nature. 376:260-263.

8. Valiante, N.M., and Trinchieri, G. 1993. Identification of a novel signal transduction surface molecule on human cytotoxic lymphocytes. J. Exp. Med. 178:1397-1406.

9. Tangye, S.G., et al. 1999. Cutting edge: human 2B4, an activating NK cell receptor, recruits the protein tyrosine phosphatase SHP-2 and the adaptor signaling protein SAP. J. Immunol. 162:6981-6985.

10. Bottino, C., et al. 2001. NTB-A, a novel SH2D1Aassociated surface molecule contributing to the inability of natural killer cells to kill Epstein-Barr virus-infected B cells in X-linked lymphoproliferative disease. J. Exp. Med. 194:235-246.

11. Martin, M., et al. 2001. CD84 functions as a homophilic adhesion molecule and enhances IFNgamma secretion: adhesion is mediated by Ig-like domain 1. J. Immunol. 167:3668-3676.

12. Sayos, J., et al. 2001. Cell surface receptors Ly-9 and CD84 recruit the X-linked lymphoproliferative disease gene product SAP. Blood. 97:3867-3874.

13. Tangye, S.G., van de Weerdt, B.C., Avery, D.T., and Hodgkin, P.D. 2002. CD84 is up-regulated on a major population of human memory B cells and recruits the $\mathrm{SH} 2$ domain containing proteins SAP and EAT-2. Eur. J. Immunol. 32:1640-1649.

14. Tangye, S.G., Nichols, K.E., Hare, N.J., and van de Weerdt, B.C. 2003. Functional requirements for interactions between CD84 and Src homology 2 domaincontaining proteins and their contribution to human T cell activation. J. Immunol. 171:2485-2495.

15. Czar, M.J., et al. 2001. Altered lymphocyte responses and cytokine production in mice deficient in the X-linked lymphoproliferative disease gene SH2D1A/DSHP/SAP. Proc. Natl. Acad. Sci. U. S. A 98:7449-7454.

16. Wu, C., et al. 2001. SAP controls T cell responses to virus and terminal differentiation of TH2 cells. Nat. Immunol. 2:410-414.

17. Yin, L., et al. 2003. Mice deficient in the X-linked lymphoproliferative disease gene sap exhibit increased susceptibility to murine gammaherpesvirus-68 and hypo-gammaglobulinemia. J. Med. Virol. 71:446-455.

18. Crotty, S., Kersh, E.N., Cannons, J., Schwartzberg, P.L., and Ahmed, R. 2003. SAP is required for generating long-term humoral immunity. Nature. 421:282-287.

19. Hron, J.D., Caplan, L., Gerth, A.J., Schwartzberg, P.L., and Peng, S.L. 2004. SH2D1A regulates Tdependent humoral autoimmunity. J. Exp. Med. 200:261-266.

20. Gordon, C.J., Grafton, G., Wood, P.M., Larche, M., and Armitage, R.J. 2001. Modelling the human immune response: can mice be trusted? Commentary. Curr. Opin. Pharmacol. 1:431-435.

21. Warnatz, K., et al. 2002. Severe deficiency of switched memory B cells (CD27(+) $\operatorname{IgM}(-) \operatorname{IgD}(-))$ in subgroups of patients with common variable immunodeficiency: a new approach to classify a heterogeneous disease. Blood. 99:1544-1551.

22. Agematsu, K., et al. 2002. Absence of memory B cells in patients with common variable immunodeficiency. Clin. Immunol. 103:34-42.

23. Hutloff, A., et al. 1999. ICOS is an inducible T-cell co-stimulator structurally and functionally related to CD28. Nature. 397:263-266.

24. Rousset, F., et al. 1992. Interleukin 10 is a potent growth and differentiation factor for activated human B lymphocytes. Proc. Natl. Acad. Sci. U. S. A. 89:1890-1893.

25. Go, N.F., et al. 1990. Interleukin 10, a novel B cell stimulatory factor: unresponsiveness of $\mathrm{X}$ chromosome-linked immunodeficiency B cells. J. Exp. Med. 172:1625-1631.

26. Tangye, S.G., Phillips, J.H., Lanier, L.L., and Nichols, K.E. 2000. Cutting edge: Functional requirement for SAP in 2B4-mediated activation of human natural killer cells as revealed by the $\mathrm{X}$-linked lymphoproliferative syndrome. J. Immunol. 165:2932-2936.

27. Arico, M., et al. 2001. Hemophagocytic lymphohistiocytosis due to germline mutations in SH2D1A, the X-linked lymphoproliferative disease gene. Blood. 97:1131-1133.

28. Brandau, O., et al. 1999. Epstein-Barr virus-negative boys with non-Hodgkin lymphoma are mutated in the SH2D1A gene, as are patients with X-linked lymphoproliferative disease (XLP). Hum. Mol. Genet. 8:2407-2413

29. Tangye, S.G., Liu, Y.J., Aversa, G., Phillips, J.H., and de Vries, J.E. 1998. Identification of functional human splenic memory B cells by expression of CD148 and CD27. J. Exp. Med. 188:1691-1703.

30. Klein, U., Rajewsky, K., and Kuppers, R. 1998. Human immunoglobulin (Ig) M+IgD+ peripheral blood B cells expressing the CD27 cell surface antigen carry somatically mutated variable region genes: CD27 as a general marker for somatically mutated (memory) B cells. J. Exp. Med. 188:1679-1689.

31. Agematsu, K., et al. 1997. B cell subpopulations separated by CD27 and crucial collaboration of $\mathrm{CD} 27+\mathrm{B}$ cells and helper T cells in immunoglobulin production. Eur. J. Immunol. 27:2073-2079.

32. Klein, U., Kuppers, R., and Rajewsky, K. 1997. Evidence for a large compartment of IgM-expressing memory B cells in humans. Blood. 89:1288-1298.

33. Tangye, S.G., Ferguson, A., Avery, D.T., Ma, C.S., and Hodgkin, P.D. 2002. Isotype switching by human B cells is division-associated and regulated by cytokines. J. Immunol. 169:4298-4306.

34. Shlapatska, L.M., et al. 2001. CD150 association with either the SH2-containing inositol phosphatase or the $\mathrm{SH} 2$-containing protein tyrosine phosphatase is regulated by the adaptor protein SH2D1A. J. Immunol. 166:5480-5487.

35. Hodgkin, P.D., Lee, J.H., and Lyons, A.B. 1996. B cell differentiation and isotype switching is related to division cycle number. J. Exp. Med. 184:277-281.

36. Lindsten, T., et al. 1982. Immune deficiency in the X-linked lymphoproliferative syndrome. II. Immunoregulatory $\mathrm{T}$ cell defects. J. Immunol. 129:2536-2540.

37. de Jong, R., et al. 1992. The CD27-subset of peripheral blood memory CD4+ lymphocytes contains functionally differentiated $\mathrm{T}$ lymphocytes that develop by persistent antigenic stimulation in vivo. Eur. J. Immunol. 22:993-999.

38. Campbell, J.J., et al. 2001. CCR7 expression and memory $\mathrm{T}$ cell diversity in humans. J. Immunol. 166:877-884

39. Hirohata, S., Jelinek, D.F., and Lipsky, P.E. 1988. $\mathrm{T}$ cell-dependent activation of $\mathrm{B}$ cell proliferation and differentiation by immobilized monoclonal antibodies to CD3. J. Immunol. 140:3736-3744.

40. Malbran, A., et al. 2004. Loss of circulating CD27+ memory B cells and CCR4+ $\mathrm{T}$ cells occurring in association with elevated EBV loads in XLP patients surviving primary EBV infection. Blood. 103:1625-1631.

41. Sornasse, T., Larenas, P.V., Davis, K.A., de Vries, J.E. and Yssel, H. 1996. Differentiation and stability of $\mathrm{T}$ helper 1 and 2 cells derived from naive human neonatal CD4+ T cells, analyzed at the single-cell level. J. Exp. Med. 184:473-483.

42. Grimbacher, B., Warnatz, K., and Peter, H.H. 2003. The immunological synapse for B-cell memory: the role of the ICOS and its ligand for the longevity of humoral immunity. Curr. Opin. Allergy Clin. Immunol. 3:409-419.

43. Snapper, C.M., and Paul, W.E. 1987. Interferongamma and B cell stimulatory factor- 1 reciprocally regulate Ig isotype production. Science. 236:944-947.

44. Davidson, D., et al. 2004. Genetic evidence linking $\mathrm{SAP}$, the X-linked lymphoproliferative gene product, to Src-related kinase FynT in $\mathrm{T}(\mathrm{H}) 2$ cytokine regulation. Immunity. 21:707-717.

45. Cannons, J.L., et al. 2004. SAP regulates $\mathrm{T}(\mathrm{H}) 2$ differentiation and PKC-theta;-mediated activation of NF-kappaB1. Immunity. 21:693-706.

46. Grierson, H.L., Skare, J., Hawk, J., Pauza, M., and Purtilo, D.T. 1991. Immunoglobulin class and subclass deficiencies prior to Epstein-Barr virus infection in males with X-linked lymphoproliferative disease. Am. J. Med. Genet. 40:294-297.

47. Ochs, H.D., et al. 1983. X-linked lymphoproliferative syndrome: abnormal antibody responses to bacteriophage phi X 174. Birth Defects Orig. Artic. Ser. 19:321-323.

48. Helminen, M., Lahdenpohja, N., and Hurme, M. 1999. Polymorphism of the interleukin-10 gene is associated with susceptibility to Epstein-Barr virus infection. J. Infect. Dis. 180:496-499.

49. Deenick, E.K., Gett, A.V., and Hodgkin, P.D. 2003. Stochastic model of $\mathrm{T}$ cell proliferation: a calculus revealing IL-2 regulation of precursor frequencies, cell cycle time, and survival. J. Immunol. 170:4963-4972.

50. Briere, F., Servet-Delprat, C., Bridon, J.M., SaintRemy, J.M., and Banchereau, J. 1994. Human interleukin 10 induces naive surface immunoglobulin $\mathrm{D}+(\mathrm{sIgD}+) \mathrm{B}$ cells to secrete IgG1 and IgG3. J. Exp. Med. 179:757-762.

51. Nurieva, R.I., et al. 2003. Transcriptional regulation of th2 differentiation by inducible costimulator. Immunity. 18:801-811.

52. Hutloff, A., et al. 2004. Involvement of inducible costimulator in the exaggerated memory B cell and plasma cell generation in systemic lupus erythematosus. Arthritis Rheum. 50:3211-3220.

53. Iwai, H., et al. 2003. Involvement of inducible costimulator-B7 homologous protein costimulatory pathway in murine lupus nephritis. J. Immunol. 171:2848-2854.

54. Chtanova, T., et al. 2004. T follicular helper cells express a distinctive transcriptional profile, reflecting their role as non-Th1/Th2 effector cells that provide help for B cells. J. Immunol. 173:68-78.

55. Kim, C.H., et al. 2001. Subspecialization of CXCR5+ $\mathrm{T}$ cells: B helper activity is focused in a germinal center-localized subset of CXCR5+ T cells. J. Exp. Med. 193:1373-1381.

56. Ozaki, K., et al. 2002. A critical role for IL-21 in regulating immunoglobulin production. Science. 298: $1630-1634$.

57. Pene, J., et al. 2004. Cutting edge: IL-21 is a switch factor for the production of IgG1 and IgG3 by human B cells. J. Immunol. 172:5154-5157.

58. Yagi, J., et al. 2003. Regulatory roles of IL-2 and IL-4 in H4/inducible costimulator expression on activated CD4+ T cells during Th cell development. J. Immunol. 171:783-794.

59. Spits, H., et al. 1983. Characterization of monoclonal antibodies against cell surface molecules associated with cytotoxic activity of natural and activated killer cells and cloned CTL lines. Hybridoma. 2:423-437.

60. Dupre, L., et al. 2004. Lentiviral vector-mediated gene transfer in T cells from Wiskott-Aldrich syndrome patients leads to functional correction. Mol. Ther. 10:903-915. 